\title{
Provision of value innovation when creating tourism clusters based on the concept of sustainable construction
}

\author{
Alexandr Orlov ${ }^{1, *}$ \\ ${ }^{1}$ Moscow State University of Civil Engineering, 129337, Yaroslavskoye shosse, 26, Moscow, Russia
}

\begin{abstract}
This article deals with the analysis of prospects and problems of tourism development in Russia. To ensure the accelerated growth of the tourism industry, it is necessary to pay special attention to the development of the infrastructure of tourist territories based on the concept of sustainable construction. In addition to the concept of sustainable construction that takes into account environmental, social and economic factors of investment and construction projects implementation, it is also proposed to use the cluster approach for the development of tourist territories. Being an example of an investment and construction megaproject, the tourism cluster has a number of specific features, such as complex management, risks of exceeding the estimated cost and failure to meet the deadlines for the implementation, which shall also be taken into account when developing the concept of tourism clusters. The article proposes an algorithm for developing the concept of a tourism cluster that provides for value innovation. Value innovation is an important element in ensuring the competitiveness of the tourism cluster and is closely linked to technical innovations in construction. The proposed algorithm takes into account domestic and foreign experience in the field of sustainable construction, existing certification systems for green, sustainable buildings, as well as the life cycle cost (LCC) estimate. The article also provides and analyzes groups of factors of tourist factors competitiveness and on their basis the strategy canvas was created for projects that are being implemented, for projects that have been implemented and for projects that can be implemented on the basis of the concept of sustainable construction. LCCs before and after the introduction of innovative technical solutions were simulated for individual facilities of Baikal tourism and recreation cluster in Russia.
\end{abstract}

\section{Introduction}

For many countries of the modern world the development of tourist activities is a priority area for the economic development. Tourism in Russia is an actively developing sector of

\footnotetext{
* Corresponding author: alor333@gmail.com
} 
the economy, in which more than 500 thousand people are involved. The potential for tourism development in Russia is quite high; the spatial and territorial extent, the uniqueness of natural zones, landscapes, and specially protected territories can be used to achieve the necessary social and economic effect. At the same time it is worth noting that according to the Federal Tourism Agency the share of tourism in GDP of Russia is only $3.8 \%$, which is about 3 times less as compared to the whole world. Noting the prospects and potential for the development of the industry, scientists and specialists pay attention to such negative factors as the poorly developed infrastructure, quality control, sustainable management and other aspects [1-3] that impede the development of domestic and inbound tourism in Russia.

One of the priority areas for the development of the tourism industry in Russia is the creation of the tourist infrastructure, including real estate for various functional purposes, roads, infrastructure facilities, etc. (trunk and tourist infrastructure). At the same time it is supposed to use the cluster approach [4-6], which allows combining efforts of various industry participants aimed at the creation of a high-quality tourist product. The main areas of tourism development at the moment are outlined in the Strategy for the Development of Tourism in the Russian Federation for the period until 2035 approved in 2019.

It should be noted that despite the fact that the Strategy mentions environmental, economic and socio-cultural aspects of tourism development, at the moment the introduction of green technologies and, in general, the concept of sustainable construction is at a rather low level. It is impossible to achieve the accelerated growth of the tourism industry without the active creation of the infrastructure of tourism clusters, and this, in turn, creates the so-called environmental load on the tourist territory. The environmental load represents a combined impact of all sources on the environment and/or individual components of the natural environment within the tourist territory (cluster). The implementation of the concept of sustainable construction [7, 8] involves consideration of not only environmental, but also social and economic aspects of investment construction projects implementation. The analysis of foreign experience shows that the creation of sustainable buildings and territories requires an integrated approach to the implementation of investment and construction megaprojects taking into account the interest of all participants in the investment process at all stages of the life cycle [9-11]. The experience and plans for tourism development in foreign countries, including the EU, is of practical interest, where the tourism policy, in particular, within the Tourism Manifesto For Growth\&Jobs, is based on the principles of sustainable development. In turn, these principles and goals are reflected in Reflection Paper "Sustainable Europe by 2030", which, inter alia, talks about the development of sustainable cities and communities, innovation, infrastructure development, as well as responsible production and consumption.

The analysis showed that there is no clearly formulated approach to the assessment and implementation of innovative solutions within the framework of tourism clusters infrastructure development in relation to the concept of sustainable construction, which determines the relevance of this paper. The purpose of this article is to formulate recommendations for ensuring value innovation for tourism clusters based on the concept of sustainable construction.

\section{Methodological framework for providing value innovation for tourism clusters}

The methodological framework of the presented paper is made up of the following elements:

- The concept of sustainable construction $[7,8,11]$.

- Cluster approach in the field of tourism infrastructure. 
- Analysis of the tourism cluster as a megaproject.

- Engineering approach to the evaluation of innovative solutions.

- Blue Ocean Strategy.

1. The concept of sustainable construction is based on the following groups of factors taken into account in the implementation of investment and construction projects: economic, environmental and social [12]. The conceptual foundations of sustainable construction are reflected in international systems for green certification of buildings, such as LEED, BREEAM, HQE, DGNB and others [13-16]. In Russia certification of facilities is possible both according to international standards and the domestic one - GREEN ZOOM.

The experience of the EU is of interest, where an attempt is made to create a sustainable living environment and sustainable objects based on the Level(s) system. Level(s) is a voluntary reporting system to increase the sustainability of buildings. Using the existing standards, Level(s) provides a common approach of the EU to assessing the environmental performance in the creation and development of a living environment. Level(s) is a tool for the design and construction of sustainable buildings [17, 18]. Sustainable buildings use less energy and materials, are more attractive and more convenient places for residents. Along with a smaller environmental impact, sustainable buildings are distinguished by a relatively low cost of operation and more valuable characteristics in the long run.

When evaluating the economic efficiency of such projects, the combination of the cost of ownership and the life cycle cost (LCC) is also used along with traditional tools and indicators of the financial and economic efficiency, and LCA is carried out [19-21].

2. Cluster approach: The main area of expanding tourism services within Russia is the emergence of tourism clusters. The interpretation of the concepts of the tourism cluster and cluster formation has its own distinctive features. A cluster is a combination of enterprises, suppliers of equipment and components, specialized production and maintenance services, research and educational organizations directly related to the production and sales sectors. The cluster, in this case, is considered from the perspective of a system that can create a favorable environment for improving the conditions of competitiveness, and, as a result, for the development of the region as a whole.

3. Analysis of the tourism cluster as a megaproject: tourism clusters predominantly represent investment and construction megaprojects, during the implementation of which it is necessary to take into account interests of a large number of participants, as well as develop special organizational and managerial decisions considering their specificity and scale, including using PPP models and life cycle contracts $[22,23]$. The implementation of investment and construction megaprojects, as a rule, is fraught with such problems as increasing the implementation period, exceeding estimated costs, the complex management and efficiency evaluation [24].

4. Engineering approach to the evaluation of innovative solutions. Engineering is considered within the framework of this article as a tool to improve the efficiency of implementation of investment and construction projects based on the introduction of technical innovations. According to previous studies [25], under conditions of due justification and elaboration technical innovations (global and local) can decrease the LCC and ultimately increase the efficiency indicators of the investment and construction project.

5. Blue Ocean Strategy (BOS: the starting point of this concept is the company's desire to go beyond the existing market space and create a new market (blue ocean), in which there will be no competition as compared to the existing industries (red oceans) at least in the medium term. The creators of the concept adhere to the point of view, according to which it is possible to increase the value (quality for the customer), while ensuring the target level of costs $[26,27]$. BOS can be used in the implementation of investment and construction projects of various sizes (including projects for the development of tourism infrastructure) to ensure long-term competitiveness. At the same time BOS deals with such 
a concept as value innovation, which in most cases is broader than just technical innovation and involves a jump in value due to a wide range of technical, managerial, organizational and other decisions. Within the framework of this article the creation of value innovation is considered primarily through the introduction of technical innovations aimed at implementing the concept of sustainable construction.

The methodological tools described above and their joint use made it possible to formulate an algorithm for the development of the concept of a tourism cluster that provides for value innovation (Fig.1.).

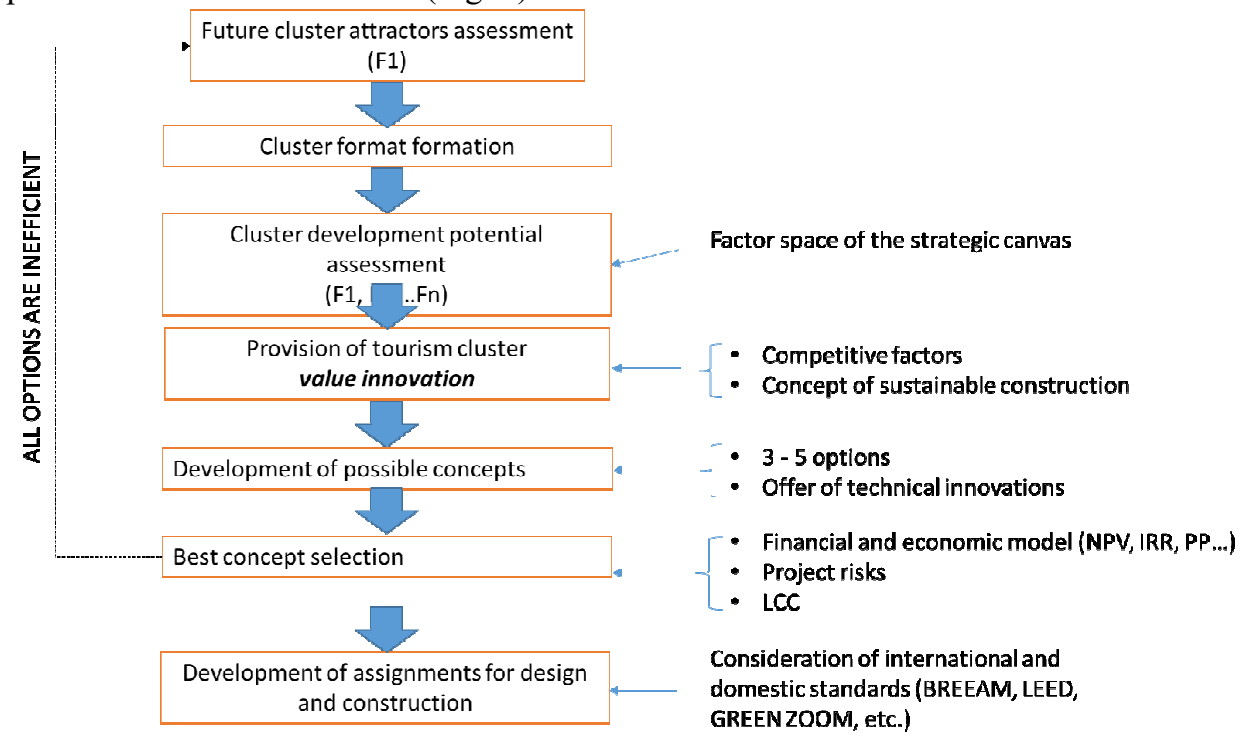

Fig.1. Algorithm for the development of the concept of a tourism cluster that provides for value innovation.

To implement the above algorithm, it is necessary to create the factor space of the strategic canvas of the tourism cluster, the strategic canvas itself, which provides for value innovation, and then analyze several options of the concept. The best option is selected based on the risk analysis of the investment and construction project using both financial and economic modeling and life cycle cost (LCA) estimates. The analysis can be carried out both for the entire investment and construction megaproject for the creation of the tourism cluster infrastructure and for individual projects within the framework of the construction of various capital construction projects (hotels, parking lots, shopping centers, etc.).

\section{Results}

Within the framework of the presented algorithm (Fig.1.) groups of factors for the formation of the strategic canvas of the tourism cluster (groups of competitive factors) were developed. It should be borne in mind that there are many types of tourism clusters that differ from each other both by tourism objectives and by scale. Of course, taking into account the specifics of an individual cluster will allow making the assessment more accurate and move from groups of factors to specific factors within the tourism cluster.

The analysis of ongoing projects in the tourism sector in Russia and abroad, as well as expert assessments of specialists and industry participants allowed identifying the following groups of factors: 
$\checkmark$ Attractors (F1): a basic group of factors that includes an assessment of the attractiveness of the destination and the availability of one or more significant centers of attraction for potential tourists (historical, natural, cultural sites, etc.).

$\checkmark$ Destination availability (F2): this group of factors takes into account the level of development of the trunk infrastructure outside the cluster (road infrastructure, the availability of destination by rail, by air and other modes of transport).

$\checkmark$ Spread of offers (F3): reflects the list of basic and auxiliary services and opportunities available to tourists within the selected tourism cluster (hotels, museums, excursions, etc.).

$\checkmark$ Infrastructure development (F4): reflects the development of the trunk infrastructure within the cluster and the quality level of tourism cluster facilities (hotels, service providers, medical facilities, museums, historical sites, etc.)

$\checkmark$ Service level (F5): reflects the overall level of service for the entire tourism product, including aspects of comfort, safety, affordability, etc.

$\checkmark$ Innovations (F6): the introduction of technical innovations within the tourism cluster aimed both at improving the level of service (F5) and at implementing the concept of sustainable construction.

$\checkmark$ Sustainable construction (F7): ensuring the sustainable development of the territory where the tourism cluster is located, taking into account environmental, social and sociocultural, as well as economic factors.

Table 1 shows the impact of groups of competitive factors on the main, direct and indirect participants in the investment and construction megaproject of the tourism cluster.

Table 1. Analysis of groups of competitive factors.

\begin{tabular}{|c|c|c|c|c|}
\hline \multirow{2}{*}{$\begin{array}{l}\text { Group of } \\
\text { competitive factors }\end{array}$} & \multicolumn{4}{|c|}{$\begin{array}{l}\text { Impact on direct and indirect participants in the investment and construction } \\
\text { megaproject of the tourism cluster }\end{array}$} \\
\hline & Consumers & Investors & State & Population \\
\hline F1: Attractors & $\begin{array}{c}\text { Increased } \\
\text { demand from } \\
\text { potential } \\
\text { consumers due } \\
\text { to the } \\
\text { attractiveness of } \\
\text { the destination }\end{array}$ & $\begin{array}{c}\text { Improved } \\
\text { efficiency of } \\
\text { investment and } \\
\text { construction } \\
\text { projects }\end{array}$ & $\begin{array}{c}\text { Improved } \\
\text { investment } \\
\text { attractiveness of } \\
\text { the region, } \\
\text { country, creation } \\
\text { of a favorable } \\
\text { image }\end{array}$ & $\begin{array}{c}\text { New jobs, urban } \\
\text { infrastructure } \\
\text { development }\end{array}$ \\
\hline $\begin{array}{l}\text { F2: Destination } \\
\text { availability }\end{array}$ & $\begin{array}{l}\text { Cost reduction, } \\
\text { increased } \\
\text { demand }\end{array}$ & $\begin{array}{l}\text { Reduction in } \\
\text { investment costs, } \\
\text { revenue growth } \\
\text { due to new } \\
\text { demand }\end{array}$ & $\begin{array}{c}\text { Creation of a } \\
\text { favorable image, } \\
\text { achievement of } \\
\text { strategic goals } \\
\text { for the } \\
\text { development of } \\
\text { tourism }\end{array}$ & $\begin{array}{l}\text { Development of } \\
\text { the transport } \\
\text { infrastructure } \\
\text { within the } \\
\text { country, region, } \\
\text { city }\end{array}$ \\
\hline F3: Spread of offers & $\begin{array}{c}\text { Increased } \\
\text { attractiveness of } \\
\text { destination, } \\
\text { creation of } \\
\text { additional } \\
\text { demand }\end{array}$ & $\begin{array}{l}\text { Increased } \\
\text { revenues from the } \\
\text { implementation } \\
\text { of investment and } \\
\text { construction } \\
\text { projects }\end{array}$ & $\begin{array}{l}\text { Increased tax } \\
\text { revenues } \\
\text { (budgetary } \\
\text { effect), socio- } \\
\text { economic } \\
\text { development of } \\
\text { the territory }\end{array}$ & $\begin{array}{c}\text { New jobs, } \\
\text { increased } \\
\text { comfort of the } \\
\text { living } \\
\text { environment }\end{array}$ \\
\hline $\begin{array}{l}\text { F4: Infrastructure } \\
\text { development }\end{array}$ & $\begin{array}{c}\text { Increased } \\
\text { attractiveness of } \\
\text { destinations, } \\
\text { increased } \\
\text { demand }\end{array}$ & $\begin{array}{l}\text { Increased } \\
\text { revenues due to } \\
\text { increased } \\
\text { demand, } \\
\text { additional costs }\end{array}$ & $\begin{array}{l}\text { Socio-economic } \\
\text { development, } \\
\text { increased } \\
\text { investment } \\
\text { attractiveness of } \\
\text { the country, } \\
\text { region, city }\end{array}$ & $\begin{array}{l}\text { Possible increase } \\
\text { in the comfort of } \\
\text { the living } \\
\text { environment }\end{array}$ \\
\hline
\end{tabular}




\begin{tabular}{|c|c|c|c|c|}
\hline \multirow{2}{*}{$\begin{array}{l}\text { Group of } \\
\text { competitive factors }\end{array}$} & \multicolumn{4}{|c|}{$\begin{array}{l}\text { Impact on direct and indirect participants in the investment and construction } \\
\text { megaproject of the tourism cluster }\end{array}$} \\
\hline & Consumers & Investors & State & Population \\
\hline F5: Service level & $\begin{array}{c}\text { Increased } \\
\text { attractiveness of } \\
\text { destinations, } \\
\text { increased } \\
\text { demand }\end{array}$ & $\begin{array}{c}\text { Additional costs, } \\
\text { increased } \\
\text { revenues }\end{array}$ & $\begin{array}{l}\text { Creation of a } \\
\text { favorable image } \\
\text { of the country, } \\
\text { region, city }\end{array}$ & $\begin{array}{l}\text { Possible increase } \\
\text { in the comfort of } \\
\text { the living } \\
\text { environment }\end{array}$ \\
\hline F6: Innovation & $\begin{array}{l}\text { Additional } \\
\text { factor for } \\
\text { increasing the } \\
\text { attractiveness of } \\
\text { the tourism } \\
\text { product and } \\
\text { improving the } \\
\text { service }\end{array}$ & $\begin{array}{l}\text { Possible increase } \\
\text { in investment } \\
\text { costs, reduced } \\
\text { LCC }\end{array}$ & $\begin{array}{c}\text { Innovative } \\
\text { development } \\
\text { (country, region, } \\
\text { city), stimulation } \\
\text { the introduction } \\
\text { of energy- } \\
\text { efficient and } \\
\text { "green" } \\
\text { technologies }\end{array}$ & $\begin{array}{l}\text { Possible increase } \\
\text { in the comfort of } \\
\text { the living } \\
\text { environment, } \\
\text { environmental } \\
\text { improvement }\end{array}$ \\
\hline $\begin{array}{l}\text { F7: Sustainable } \\
\text { construction }\end{array}$ & $\begin{array}{l}\text { Possible } \\
\text { increase in costs, } \\
\text { improvement of } \\
\text { the quality and } \\
\text { service in the } \\
\text { territories of } \\
\text { sustainable } \\
\text { development }\end{array}$ & $\begin{array}{l}\text { Possible increase } \\
\text { in investment } \\
\text { costs, reduced } \\
\text { LCC, increased } \\
\text { efficiency of } \\
\text { investment and } \\
\text { construction } \\
\text { projects in the } \\
\text { long term }\end{array}$ & $\begin{array}{l}\text { Ensuring } \\
\text { sustainable } \\
\text { development of } \\
\text { the territory } \\
\text { (country, region, } \\
\text { city), creation of } \\
\text { a favorable } \\
\text { image }\end{array}$ & $\begin{array}{l}\text { Creation of a } \\
\text { sustainable living } \\
\text { environment }\end{array}$ \\
\hline
\end{tabular}

Based on the presented groups of factors 2 strategic canvases were developed: for the tourism clusters existing in Russia and clusters where it is planned to ensure value innovation. The results are presented in Fig. 2.

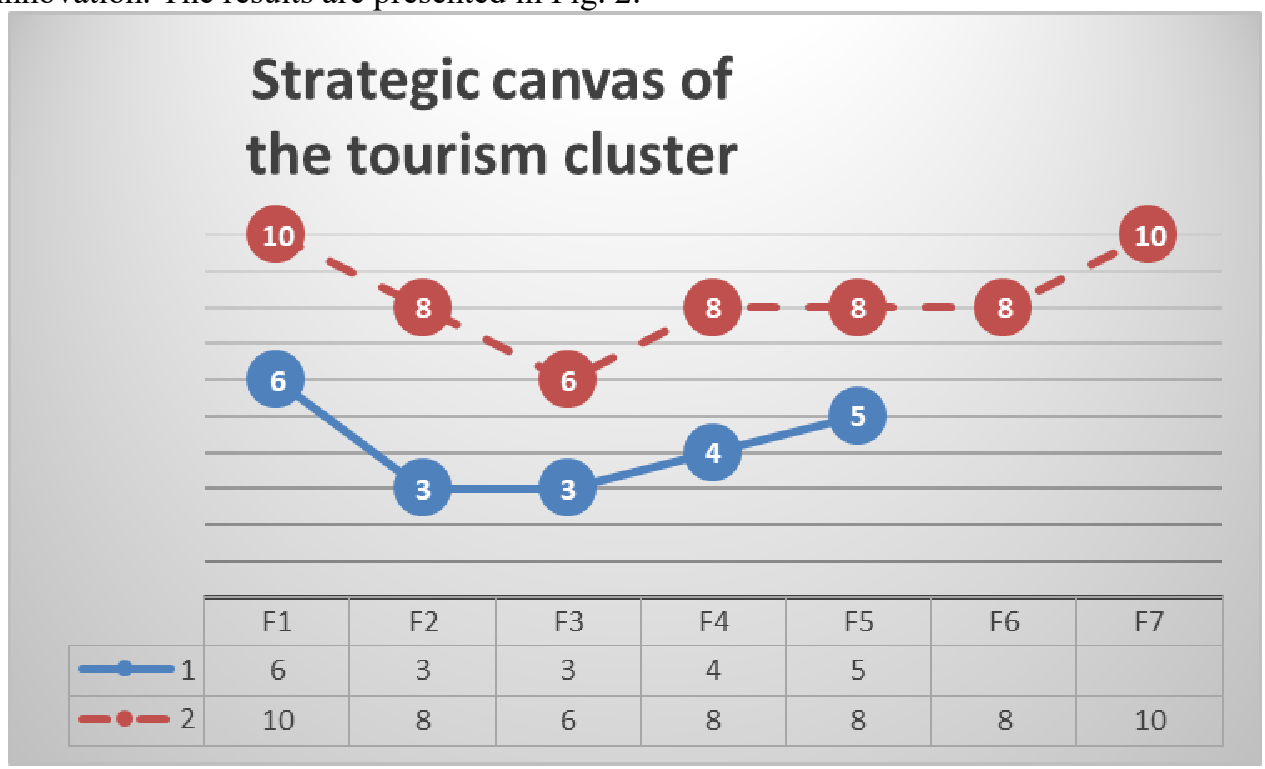

Fig.2. Creation of the strategic canvas of the tourism cluster.

The groups of factors were assessed expertly using a 10-point rating scale. Line 1 in Fig.2. shows the current situation with tourism clusters in Russia (in general form). As we can see, insufficient attention is paid to all groups of factor, which, while maintaining the approach, will not ensure the long-term competitiveness of tourist destinations in Russia. 
Particular attention should be paid to F6 and F7, which at the moment in most cases are not considered at all as factors of competitiveness.

Technical innovations (F6) and the implementation of the sustainable construction concept (F7) are reflected by line 2, which represents a simulated strategic canvas aimed at ensuring value innovation and long-term competitiveness. Changes are also required for groups of factors F1-F5, more attention to which is needed.

The methodological approach described above was used to forecast the total cost of ownership of hotel real estate within the framework of Baikal tourism and recreation cluster (Irkutsk region). Measures to reduce the negative impact on the environment were considered on the example of the use of materials dictated by GREEN ZOOM standard in construction, and measures that reduce the inappropriate use of water resources and electricity were also justified.

As a private example the use of solar panels and collectors that replaced "standard" energy sources was considered. Solar panels and flat-type collectors were taken as the basis. The required number of solar panels for a cottage with an area of $150 \mathrm{~m} 2$ was determined, as well as the demand for components for solar collectors was calculated. The total efficiency of using the described installations was calculated by comparing the costs for the operation of cottages using the solar power system and without it. As it turned out, the initial investments in the solar power system are fully justified, since they significantly reduce energy costs during operation, which positively affects the environmental situation in Baikal cluster.

The life cycle cost (LCC) of the building was estimated taking into account total costs. The calculations were made using average values for one year of operation and compared with the life cycle cost of a standard cottage. The results are presented in Table 2.

Table 2. . The results

\begin{tabular}{|c|c|c|c|}
\hline Name & Unit & Standard house & Efficient house \\
\hline $\begin{array}{c}\text { Total one-time life cycle } \\
\text { costs }\end{array}$ & Rub. & $5,738,400$ & $7,939,533$ \\
\hline $\begin{array}{c}\text { Total periodic life cycle } \\
\text { costs }\end{array}$ & Rub. & $9,963,130$ & $3,997,096$ \\
\hline $\begin{array}{c}\text { Correction factor } \\
\text { (seasonality, building } \\
\text { energy efficiency class) }\end{array}$ & Rub. & 1.00 & 1.00 \\
\hline $\begin{array}{c}\text { Total life cycle costs } \\
\text { Years of the planning } \\
\text { period (P) }\end{array}$ & Rub. & $15,701,530$ & $11,936,629$ \\
\hline $\begin{array}{c}\text { Average annual } \\
\text { cumulative costs for the } \\
\text { life cycle of the building }\end{array}$ & Rub. & $1,046,768$ & 15 \\
\hline Total area of the object & sq. m & $\underline{795,775}$ \\
\hline $\begin{array}{c}\text { Cost value of the } \\
\text { building life cycle per } \\
\text { unit area per year }\end{array}$ & $\begin{array}{c}\text { Rub. per } 1 \\
\text { sq.m of the } \\
\text { total area of } \\
\text { the facility }\end{array}$ & $\underline{\mathbf{5 , 2 3 4}}$ & $\underline{\mathbf{3 , 9 7 8}}$ \\
\hline $\begin{array}{c}\text { FOR REFERENCE: } \\
\text { Cost value of the } \\
\text { building life cycle per } \\
\text { unit area per year }\end{array}$ & $\begin{array}{c}\text { USD per } 1 \\
\text { sq.m of the } \\
\text { facility }\end{array}$ & & $\underline{\mathbf{6 3 . 1 4}}$ \\
\hline
\end{tabular}

So, the cost of the life cycle of a cottage built using innovative technologies based on the concept of sustainable construction without discounting amounted to 3,978 rubles per 1 sq. $m$ per year, which shows the efficiency of the use of "sustainable" construction technologies on the example of the cluster under consideration. 


\section{Discussion}

The presented results of the work can be used by the participants in investment and construction megaprojects for the creation and development of clusters at the private and state levels to form a sustainable concept for territory development, as well as to analyze the efficiency of the implementation of various technical innovative solutions. At the same time, taking into account the specifics of each cluster, an individual strategic canvas for a specific investment and construction megaproject should be formed considering the format of the facility, climatic, environmental, technical and other construction conditions.

The implementation of a detailed algorithm for developing the concept of a tourism cluster that provides for value innovation should result in more competitive and efficient tourism clusters that create value for the consumer and ensure sustainable development of territories.

\section{Conclusion}

Further studies on the issue of sustainable construction can relate to both detailing the recommendations presented for various types and formats of clusters and going beyond tourism clusters, since issues of sustainable development of territories are important for megaprojects of completely different areas. At the same time one should take into account the presence of gaps in the normative and technical regulation of construction in the Russian Federation, in particular, the insufficient flexibility of approaches to the design of capital construction projects with the introduction of innovative solutions, the absence of estimated standards for the operation of real estate items at the federal level, which makes it difficult to assess the cost of the life cycle.

\section{References}

1. B. Algieri, An econometric estimation of the demand for tourism: The case of Russia. Tour. Econom. 12(1), pp. 5-20 (2006) DOI: 10.5367/000000006776387114

2. L. Andrades, F. Dimanche, Destination competitiveness and tourism development in Russia: Issues and challenges. Tour. Manag. 62, pp. 360-376 (2017) DOI: 10.1016/j.tourman.2017.05.008

3. J.V. Nikolaeva, N.M. Bogoliubova, S.S. Shirin, Ecological tourism in the state image policy structure. Exp. and prob. of modern Russ. Curr. Iss. in Tour. 21(5), pp. 547-566 (2018) DOI: 10.1080/13683500.2015.1100588

4. M. Novelli, B. Schmitz, T. Spencer, Networks, clusters and innovation in tourism: A UK experience. Tour. Manag., 27(6), pp. 1141-1152 (2006) DOI: 10.1016/j.tourman.2005.11.011

5. A. Alexandrova, Y. Vladimirov, Tourism clusters in Russia: What are their key features. The case of Vologda region. Worldwide Hosp. and Tour. Them. 8(3), pp. 346-358 (2016) DOI: 10.1108/WHATT-02-2016-0007

6. N. Kim, C. Shim, Social capital, knowledge sharing and innovation of small- and medium-sized enterprises in a tourism cluster. Int. J. of Cont. Hosp. Manag. 30(6), pp. 2417-2437 (2018) DOI: 10.1108/IJCHM-07-2016-0392

7. Y.-J. She, Y.-H. Zhu, Q. Huang, System of sustainable construction based on project whole life cycle management. Ad. Mat. Res. 403-408, pp. 2093-2097 (2012) DOI: 10.4028/www.scientific.net/AMR.403-408.2093 
8. M.M. Matar, M.E. Georgy, M.E. Ibrahim, Sustainable construction management: Introduction of the operational context space (OCS). Constr. Manag. and Ec. 26(3), pp. 261-275 (2008) DOI: 10.1080/01446190701842972

9. E. Conte, V. Monno, Beyond the buildingcentric approach: A vision for an integrated evaluation of sustainable buildings. Envir. Imp. Ass. Rev. 34, pp. 31-40 (2012) DOI: 10.1016/j.eiar.2011.12.003

10. G. Baird, A. Leaman, J. Thompson, A comparison of the performance of sustainable buildings with conventional buildings from the point of view of the users. Arch. Scie. Rev. 55(2), pp. 135-144 (2012) DOI: 10.1080/00038628.2012.670699

11. N. Wang, H. Adeli, Sustainable building design. J. of Civ. Eng. and Manag. 20(1), pp. 1-10 (2014) DOI: 10.3846/13923730.2013.871330

12. L.V. Prykina, A.K. Orlov, Peculiar Features for the Consideration of Ecological and Economical Aspects of the Course of Underground Construction. Proc. Eng. 165, pp. 1388-1394 (2016) DOI: 10.1016/j.proeng.2016.11.869

13. T. Meshcheryakova, Problems of the development of international standards of "green building" in Russia. IOP Conf. Ser.: Earth and Envir. Scie. 90(1), 012118 (2017) DOI: 10.1088/1755-1315/90/1/012118

14. E. Bernardi, S. Carlucci, C. Cornaro, R.A. Bohne, An analysis of the most adopted rating systems for assessing the environmental impact of buildings. Sustainability (Switzerland) 9(7), 1226 (2017) DOI: 10.3390/su9071226

15. R.K. Zimmermann, O. Skjelmose, K.G. Jensen, K.K. Jensen, H. Birgisdottir, Categorizing Building Certification Systems According to the Definition of Sustainable Building. IOP Conf. Ser.: Mat. Scie. and Eng. 471(9), 092060 (2019) DOI: 10.1088/1757-899X/471/9/092060

16. E. Vazquez, M. Miguez, L. Alves, J. Valente, G. Rossi, Certifications in construction: A case study comparing LEED and HQE. WIT Trans. on Ecol. and the Envir. 144, pp. 253-264 (2011) DOI: 10.2495/ECO110231

17. K. Kanafani, F.N. Rasmussen, R.K. Zimmermann, H. Birgisdottir, Adopting the EU Sustainable Performance Scheme Level(s) in the Danish Building Sector. IOP Conf. Ser.: Mat. Scie. and Eng. 471(9), 092070 (2019) DOI: 10.1088/1757899X/471/9/09207

18. H.J. Bernegger, New Portfolio-Rating-System based on LEVEL(S). IOP Conf. Ser.: Earth and Envir. Scie. 323(1), 012038 (2019) DOI: 10.1088/1755-1315/323/1/012038

19. P. Gluch, H. Baumann, The life cycle costing (LCC) approach: A conceptual discussion of its usefulness for environmental decision-making. Build. and Envir. 39(5), pp. 571-580 (2004) DOI: 10.1016/j.buildenv.2003.10.008

20. Z. Yan, Green construction economy research based on LCC theory. Open Cyb. and Syst. J. p, p. 2805-2810 (2015) 10.2174/1874110X01509012805

21. P. Grabovy, A. Orlov, Management of the LCC considering industrial construction life cycle contracts. MATEC Web of Conf. 251, 05019 (2018) DOI: 10.1051/matecconf/201825105019

22. P. Boateng, D. Ahiaga-Dagbui, Z. Chen, S. Ogunlana: Modelling economic risks in megaproject construction: A systemic approach. Proc.of the 31st Ann. Assoc. of Res. in Constr. Manag. Conf., ARCOM, pp. 115-124 (2015)

23. Y. Hu, A.P.C. Chan, Y. Le, R.-Z. Jin, From construction megaproject management to complex project management: Bibliographic analysis. J. of Manag. in Eng. 31(4), 4014052 (2015) DOI: 10.1061/(ASCE)ME.1943-5479.0000254 
24. B. Flyvbjerg, What you should know about megaprojects and why: An overview. Proj. Manag. J., 45 (2), pp. 6-19 (2014) DOI: 10.1002/pmj.21409

25. A. Orlov, Introduction of innovative technical solutions in construction on the basis of the concept of engineering. IOP Conf. Ser.: Mat. Science and Eng. 365(6), 062020 (2018) DOI: 10.1088/1757-899X/365/6/062020

26. W.C. Kim, R. Mauborgne, Blue ocean leadership. Harv. Busin. Rev., 92 (5), pp. 60-68, 70, 72 passim. (2014)

27. W.C. Kim, R. Mauborgne, Red ocean traps. Harv. Busin. Rev., pp. 1-7 (2015) 